\title{
EDUCATIONAL VALUES IN ENGLISH ISLAMIC SONG LYRICS OF SAMI YUSUF ALBUM
}

\author{
Silvia Gestiana \\ LAIN Metro, Lampung \\ silviagestiana030897@gmail.com

\section{Kuryani} \\ IAIN Metro, Lampung \\ kuryaniutih@gmail.com \\ Linda Septiyana \\ IAIN Metro, Lampung \\ lindaseptiyana@metrouniv.ac.id
}

\begin{abstract}
Educational values can influence people's behaviour and daily life. Besides, educational values can create good characters of human beings. This study aims : 1) to find out educational values in English Islamic song lyrics of Sami Yusuf album and 2) to analyze educational values in English Islamic song lyrics of Sami Yusuf album. This research is a content analysis study that includes descriptive analysis. The data collecting techniques used by researchers were observation and documentation. The result shows the educational values that are found in Sami Yusuf's song lyrics deal with honesty, courage, peace, self-reliance \& potential, self-discipline \& moderation, loyalty \& dependability, respect, love, sensitive \& unselfishness, kindness \& friendliness, and justice \& mercy. The highest educational value that is found is honesty which is $19 \%$, while the least are peace, respect, and love that are only found once with a percentage of 3\% each of them. Therefore, it is recommended for English teacher to use English Islamic song lyrics in Sami Yusuf album as a medium in teaching and learning. Teachers do not have to worry because the songs in this album contain a variety of positive values that can be used in the learning process.
\end{abstract}

Keywords : Educational Value, Moral Value, Islamic Songs, Sami Yusuf Album

\section{A. INTRODUCTION}

s a tool of communication, language plays an important role in interaction. Clark in
Luke stated that language is a tool that do tasks more efficient and to grasp the
goal (Luke, 2015). Human as social creatures need something for the interaction because human as social creatures cannot live alone. The interaction will create communication among two people or more. Through language, people can deliver what people wants because language can express the feeling or idea. Language is the most important part of determining whether or not the interaction runs well.

Language is one of the most valuable outcomes of human culture since it allows people to communicate with one another, every human being can communicate and interact with the surrounding communities. With language, humans can grow, develop and adapt various 
Gestiana, Kuryani, Septiyana, Educational values...

symptoms which appear in their environment. In social life, it is clear that language has a very significant part. Communication will run smoothly if the target language used correctly (Fitria, 2020, p. 112).

Language can be delivered by spoken or written. Written means that language is not just based on conversation. Written language can also in the form of text. In text, language is written as paragraph, sentence, phrase or word. Jan Van Luxemburg stated that text has a certain meaning. Text means a set of words can also be interpreted as a sign (language) that has a relationship among each other, between sign and user sign, or between sign and meaning or text content (Van Luxemburg, 1989). The relationship between text and sign is meaning or content.

Language can also be delivered through various media. Teachers have important role in determining the students' achievement (Rahayu \& Hizriani, n.d.). There are many media which can be used by the teachers such as movie, novel, drama, song, and etc. Song can be called language because the lyrics of a song conveys meaning.Song lyrics made by a song writer might symboli feelings or thoughts that the writers want to deliver to the listeners. The singers sing the lyrics which are meaningful with the expectation that listeners can enjoy and receive the feeling and meaning of the lyrics. Moreover, the listeners also can get the knowledge from the lyrics (Nurpahmi, 2015, p. 29). The text in the lyrics of a song that has been sung are a language of meaning. The meaning of the lyrics can be various, like message, story, advise, or value. Such meanings can give educational and moral values.

In addition, Sami Yusuf is a British Songwriter. Sami Yusuf has talent in creating music and singing from his family, especially from his father. Since childhood, Yusuf has learned music instruments and singing. Yusuf continued to develop the talents. Even though, Yusuf had the intention to back out from music. Therefore, Yusuf aspired to make a difference in the Islamic world, Yusuf learned law to support his wishes. Thankfully, because of support from best friend, Yusuf continues his singing career. Yusuf's friend told that through the song, Yusuf can still deliver a positive message and invite others to love God and Prophet. Then, Sami Yusuf kept on developing the potential and released his first album in 2003.

The album includes fifteen songs. Previously, Yusuf once said that would make music and do something dignified and respectable. Therefore, there is no wonder in the song lyrics that there are much positive things. Furthermore, researcher does not take all song lyrics of Sami Yusuf, but just took five song lyrics from wherever you are album that have interesting in educational and moral values as the object of research. 
Based on the explanation above, the researcher tried to find out and analyze the educational values in the Sami Yusuf's song lyrics, especially in the album of "Wherever You Are". It is important to know and learn that educational values have a crucial role to be taught by the students because they have impact on the students' achievement and behavior. By learning and understanding the educational values, the students will have good morals, characters, and principles in their life. Besides, the integration of educational and Islamic values in all subject, including in English as a foreign language, is crucial to do since Muslim lecturers also have a part in preserving the religious values through their classroom activities (Madkur and Muharrom Albanani in Wijayanto, 2020, p. 19).

Therefore, the purposes of this study is 1) to find out the educational values on English Islamic song lyrics of Sami Yusuf album and 2) to analyze the educational values on English Islamic song lyrics of Sami Yusuf album.

\section{B. REVIEW OF LITERATURE}

Educational values are very crucial aspects which can be found in literary works. Educational values can influence people's behaviour n daily life. Besides, educational values can create good characters of human beings. Educational value is something that helps a person enhance their essential intellectual and emotional abilities in order to live a better life (Mafiroh \& Prasetyo, 2017). Educational value is a character that helps the students to develop the cultural values and character of the nation. Therefore, the students have and apply these values in their life as members of society and citizens (Meliala et al., 2017).

Educational values are divided in two kinds. The kinds of values are values of being and values of giving. Values of being consist of honesty, courage, peace, self-reliance and potential, self discipline and moderation, and fidelity \& chastity. While in values of giving consist of loyalty \& dependability, respect, love, unselfishness \& sensitive, kindness and friendliness and last justice and mercy(Eyre \& Eyre, 1993).

According to (Ghosh, n.d.), Educational Value has a role in life. Based on Ghosh and Haryana, educational value has functions such as: 1) too bring quality for life and to keep develop activity or communication well in the society, 2) to keep in right way and guide for the human, 3) to give direction and firmness to make life well and it can bring joy and peace of life, 4) to give attention in our culture so it is can keep going on, 5) to develop morality and character, and 6) to keep the peace and harmony in the individual and society. There have been previous studies related to this research. First, it was written by Abdul Wakil. The title is 
Gestiana, Kuryani, Septiyana, Educational values...

An Analysis of Moral and Educational Values on Madura Folk Songs. From the songs, since the lyrics contain messages about the mental strength in facing dangers, the moral value is about courage, and the educational value is about brave (Wakil, 2015). The differences between this research are the song lyrics. The previous study used the lyrics of Madura song, while the researcher uses the song lyrics of Sami Yusuf.

Second, An Analysis of Indonesian Moral Values Found in the Song Lyrics Forgive Me Album by Maher Zain. The journal was written by Lutfy Fajar Hudayah in 2017. The results of this study discussed about moral values. In addition, there are several Indonesian Moral Values that are found in the song lyrics album by Maher Zain. Religiosity, love and affection and loyalty are the moral values that appear most frequently in song lyrics (Hudayah, 2017). However, the study differs from the one conducted by the researchers. The differences are in the song lyrics and value of research. In this research, the researchers analyzed the educational values.

Third, An Analysis of Educational Values in "Life of Pi" Movie. This undergraduate thesis was written by Selvy Dwi Suryati. The results showed that some educational values in the "Life of Pi" movie like: never give up, grateful, religious, peace, loyalty, diligent, not selfish, purity, respect. Furthermore, there are three benefits of watching "Life of Pi" movie. They are medium of education, medium of entertainment, source of inspiration (Suryati, 2018). The researcher used English Islamic song lyric while Suryati used a movie as an object of the research.

\section{METHOD}

This research employed qualitative research. This research used the type of content analysis research. There were two data sources of the data, primary and secondary source. Primary of this research was Sami Yusuf's song in Wherever You Are album. Moreover, secondary source is used to support the primary data. The researchers collected the data from any kinds of books, journals, articles, web- internet and other materials regarding the theories educational value, moral value, and song that were related to the research. The data collected using observation and documentation. Because it was part of the content analysis, researcher did not go in the field of observation. In observation, the researchers observed data from journals, scientific articles, and books that related with song lyrics in Wherever You Are Album. In addition, the activity in collecting documentation also created a note, described of data, and also made connection with other phenomenon. A data analysis technique was used 
Miles and Hubberman. According to Miles and Huberman, there are three activities namely data condensation, data display, and conclusion drawing \& verification.(Miles et al., 2014). In data condensation, the researchers looked, focused, and chose the needed data. After that, data of sentence was given mark, and was separated between needed or not, and then move the needed data in other places. Next, the data that reflects not just in general but also precisely and clearly. In the stage of concluding and verifying, the result of research was based on the problem of the research and the theory of educational values that was used.

\section{FINDINGS AND DISCUSSIONS}

\section{FINDINGS}

This was the first phase in analyzing the song lyrics, in order to simplify the lyrics to be easily identified. Additionally, the phase answered the problem formulation. The song lyrics was collected from the internet, then also have been analyzed and classified into each indicator that suitable at the meaning of each lyric. Researcher gave the clues for coding the lyrics, for example, the first line was marked by L1 (line one), then the second line is L2 (line two) and so on.

There were 5 English Islamic songs that were analyzed by the researchers. Namely, Wherever You Are, Salaam, Fragile World, Trials of Life, and Make me Strong. The researchers also provided coding for each song title such as Wherever You Are (WYA), Salaam (Sa), Fragile World (FW), Trials of Life (ToL), and Make me Strong (Mms). So, the researchers provided code in each lyric that was considered to have a value like 'WYA.L1' which means in Wherever You Are song on the first line, or 'ToL.L3\&L4' which means in the song Trial of Life the third and fourth lines, or Sa.L5-L7 which means in the song Salaam at the fifth to seventh lines.

\section{Educational Values that were found in English Islamic song lyrics of Sami Yusuf album}

The Educational Value which is represented in Sami Yusuf's song lyrics are:

\section{a. Honesty}

Honesty is telling the truth without changing the point. The point is based on the fact. The value of honesty that is represented in song lyrics are as follows: 
Gestiana, Kuryani, Septiyana, Educational values...

1) WYA.L3\&L4 (Everytbing fell apart, Moment I strayed from you). The lyrics explain that the singer describes the feeling of becoming far from God. The singer honestly tell about it through the lyrics.

2) WYA.L14\&L15 (Cause you're the one my heart is to, I need You) The lyrics describe the honesty of singer who says and realizes that without God, singer will cross the line. Singer makes this point because it is the fact.

3) FW.L4\&L5 (A pain I've never felt before, My heart says: "Just speak the truth") The lyrics directly represent about honesty. The value can be seen by the words 'just speak the truth'. Singer honestly speaks about anything (truth happens). The truth is singer feeling of pain.

4) FW.L12\&L13 (I don't know where I'm destined to be, Rich or poor, famous, loved or lonely) The lyrics directly represent about singer tell about the fact which does not know about his future condition, even the truth will no one know one's destiny.

5) FW.L22\&L23(Cheat and lie, have it your way, But you can't cheat death, no way). The lyrics directly represent of honesty. The value can be explained by singer tells the fact about death that will surely come and no one can escape from it.

6) MmS.L6 (Nothing in life is free). The lyrics indirectly explain about anything that has to attempt first like can be trough money, effort, or barter. The lyrics are true because it happen in our daily activity.

\section{b. Courage}

Courage is a situation where one dares to face the difficult thing like follow the truth and right, express of statement (agree or disagree), etc. The courage value that is represented in song lyrics are as follows:

1) WYA.L16\&L17 (To see your smile, I would pass every trial. The lyrics can represent courage because the lyrics directly describe that the singer dares to fight and pass many risks for a purpose.

2) ToL.L20-L22 (Trials of life upon me, Are more precious than diamonds and gold, Tested with fire I may be) The lyrics express how the singer fearlessly fought every challenge and trial and found a way to overcome them. The challenge can be life lesson.

3) FW.L7\&L8 (Need to get something off my mind? Don't let this silence be misunderstood). Because one of the characteristics of courage is that it fearlessly speaks the truth, even if it is only a statement or anything, the lyrics implicitly convey the value of courage. The important way of it is in right thing. 
4) MmS.L4\&L5 (But this waiting comes with, Trials and challenges). The lyrics might be interpreted as a symbol of bravery because they imply that despite facing numerous challenges, the singer continues to wait and fight for what he wants.

\section{c. Peace}

Peace comes from having a pleasant attitude and being in good shape. The peace value that is represented in song lyrics is:

WYA.L1\&L2 (My best times, When I felt close to you). The lyrics can convey peace value, because the phrases 'best times' indirectly explain about when the singer felt near to God, the singer feels better without worrying about anything.

\section{d. Self-reliance \& Potential}

Self-reliance means having confidence to be able to do a job. Potential is an ability possessed by a person. The self reliance \& potential values that are represented in song lyrics are as follows:

1) WYA.L9 (Wherever You are, I'll find you). The lyrics of the song directly represent about self-reliance \& potential. The lyrics 'I'll find you' explain about a sense of his confident to find God who direct singer to always in right thing and way.

2) WYA. L29\&L30 (Wherever you may be, I will search till we meet). The lyrics explain about the confidence of a singer who is aware of his abilities and has a determination to find God.

3) ToL.L23 (But I know I'll come out stronger in this world). The lyrics explain that singer believes through the abilities, singer can overcome and find solutions to all the trials given so that she can learn from the problem. The words of 'I'll come out stronger' it represented about the singer self-reliance of potential. Singer believes that can pass the trial and challenge that was given.

4) MmS.L23 (Something known only to me). The lyrics indirectly represent self-reliance, because the singer believes that he is the only one who knows what is going on.

\section{e. Self Discipline \& Moderation}

Self-discipline is the ability to recognize one's own limitations. Speaking, eating, exercising, and doing something else in moderation means acting normally (not excessively). The selfdiscipline $\&$ moderation values that are represented in song lyrics areas follows:

1) ToL.L13-L19 (Cause I don't need anyone, Nor anything in My life, But You, No I don't need anyone, To show me my way, No I don't need anyone, But You) The lyrics represent about these values. The word of 'I don't need anyone or anything' indirectly represent the 
Gestiana, Kuryani, Septiyana, Educational values...

value of self-discipline. An external influence, such as the environment or a friend, could have had a negative impact. As a result, the artist sets boundaries and picks which of his friends can help him grow as a person. The way to limit by self is a way of protection or care to singer individuality.

2) FW.L6 (But My mind says:'Don't be a fool'. The words of lyrics 'don't' directly represents that singer control. The lyrics describe that the singer holds anything that he or she doesn't have to do, even if it's just a suggestion or a direction.

3) MmS.L12 (Help me find my way). These lyrics imply that the singer is not arrogant and acknowledges that wonderful things require the assistance of others.

\section{f. Loyalty \& Dependability}

Loyalty is almost the same as fidelity. Dependability is similar with trustworthiness. The loyalty and dependability values that are represented in song lyrics are as follows:

1) WYA.L13 (Wherever you be, I'll be with you). The lyrics directly represent the values that can be found in the lyrics of "wherever" and "I'll be with you". The lyrics explain that singer will always be together and keep the words in actual deeds.

2) WYA.L18\&L19 (Desperately I await, The day when I'm by your side) The word 'await' directly shows that the singer has loyalty. These lyrics are about the singer who is always waiting for God, even if she has no idea what she will get.

3) WYA. L21\&L22 (Wherever you may be, I'll follow till I see). The lyrics 'wherever' and 'I'll follow' is directly represented as loyalty. The value will always exist, and singer always follows wherever and whenever even that loyalty is already embedded in the singer's heart.

\section{g. Respect}

Characteristics of respect are treat with good manner to others like parents, elder, nature, or statement. The respect value that is represented in song lyrics is as follows:

ToL.L27 (If that's what you decree). The lyrics can represent the value of respect because Because the singer is indirectly advising another person to make a decision. The value is represented by the word of lyrics 'what you decree'. The lyrics make singer respectful and obedient to the commandments aimed at singer.

\section{h. Love}

Love is a deeper love than affection. The characteristic is caring. The singer value that is represented in the song lyrics is as follow: 
Sa.L8\&L9 (We're here for a day or two, Let me show my way). The lyrics describe how the singer continues to truly put forth his best effort for the individual who is being addressed. As a result of the previous assistance, the person has evolved into a unique individual. It can be seen in a singer who is always concerned and generously inspires people to take a better path than the ones that have previously taken. Singer wishes to assist without expecting anything in return, such as money or anything else.

\section{i. Sensitive \& Unselfishness}

One of the sensitive characteristics is thinking too much about oneself, whereas notselfishness tries not to think too much about itself and instead thinks about others. The sensitive \& unselfishness values that are represented in song lyrics are like below:

1) Sa.L12\&L13 (When there'll be, Justice and unity). The lyrics indirectly represent about value of unselfishness. These lyrics explain about the singer's hope that the world will be better without any problem. Lyrics represent unselfishness because singer not only prays for himself but also prays for the welfare of the common.

2) ToL.L1\&L2 (My life is not same, when I'm too concerned by what they say). The Lyrics can represent the values of being sensitive because the lyrics indirectly express about the singer Who is overly sensitive and concerned about what people say, which has an impact on him or her.

3) ToL.L3 (Why should I? When I too concerned by what they say) The word of 'I' in the lyrics that is repeated twice indirectly explain about singer feels too focused on himself, so singer just goes back to being a constant topic to self.

4) MmS.L18 (I feel that I've lost touch) the repeat word of 'I' indicates that singer centers and thinks about the self individuality, when the condition is not good and lost the direction.

\section{j. Kindness \& Friendliness}

Kindness and friendliness go a long way with younger and weaker people. The ability to create and keep friends is referred to as friendliness. The kindness \& friendliness values that are represented in song lyrics are like below:

1) Sa.L8 (We're here for a day or two). The lyrics of 'we're here' directly explain about the singer who has the value of assisting and accompanying others in need.

2) Sa.L12\&L13 (When there'll be, Justice and unity). The lyrics indirectly represent values of kindness. The lyrics have explanation about the singer's hope that the world will be 
Gestiana, Kuryani, Septiyana, Educational values...

better without any problem. It shown kindness because singer have a motivation to help other without a direction or enforcement.

\section{k. Justice \& Mercy}

Justice is the value that operates under the same conditions for everyone and does not discriminate. Mercy is forgiveness. The justice \& mercy values that are represented in song lyrics areas follows:

1) Sa.L14 (Where we put aside our differences). The lyrics of 'differences' represent about justice. The lyrics explain about the singer's hope which is the world without discrimination to anyone. A world appreciates every difference of people.

2) MmS.L29 (That on that day You'll forgive me). The word 'forgive' in the lyrics directly represent mercy. The lyrics explain about the singer's expectation to no longer feel sinful and return to the right way.

3) MmS.L32 (I beg for Your mercy). The word 'Your mercy' in the lyrics directly represent of mercy. The lyrics explain about the singer's expectation to no longer feel sinful and return to the right way.

\section{Analyzing Educational And Moral Values On English Islamic Song Lyrics Of Sami Yusuf Album}

Before analyzing, this phase was done to show the finding of song lyrics that containing educational values. The data has been displayed in the table to make it easier to see as below:

Table 1 Data Coding Result of Moral Value in Sami Yusuf's Song Lyrics

\begin{tabular}{|c|c|c|c|c|c|c|}
\hline \multirow{2}{*}{\multicolumn{2}{|c|}{$\begin{array}{c}\text { Indicators of } \\
\text { Educational Values }\end{array}$}} & \multirow{2}{*}{ Avai } & \multicolumn{2}{|r|}{ Distribution } & \multirow{2}{*}{$\begin{array}{l}\text { MData } \\
\text { Findings }\end{array}$} & \multirow[t]{2}{*}{ Percentage } \\
\hline & & & Data Coding & Lyrics & & \\
\hline \multirow{5}{*}{$\begin{array}{c}\text { Values } \\
\text { of Being }\end{array}$} & \multirow[t]{5}{*}{ Honesty } & \multirow[t]{5}{*}{$\checkmark$} & WYA. L3\&L4 & $\begin{array}{l}\text { Everything fell apart } \\
\text { Moment I strayed from You }\end{array}$ & \multirow[t]{5}{*}{6} & \multirow[t]{5}{*}{$19 \%$} \\
\hline & & & WYA. L14\&L15 & $\begin{array}{l}\text { Cause you're the one my heart is to } \\
\text { I need You }\end{array}$ & & \\
\hline & & & FW.L4\&L5 & $\begin{array}{l}\text { A pain I've never felt before } \\
\text { My heart says: "Just speak the } \\
\text { truth" }\end{array}$ & & \\
\hline & & & FW.L12\&L13 & $\begin{array}{l}\text { I don't know where I'm destined to be } \\
\text { Rich or poor, famous, loved or } \\
\text { Lonely }\end{array}$ & & \\
\hline & & & FW. L22\&L23 & $\begin{array}{l}\text { Cheat and lie, have it your way } \\
\text { But you can't cheat death, no } \\
\text { Way }\end{array}$ & & \\
\hline
\end{tabular}


Volume 7, Number 01, June 2021

\begin{tabular}{|c|c|c|c|c|c|c|}
\hline & & & MmS.L6 & Nothing in life is free & & \\
\hline & Courage & $\checkmark$ & $\begin{array}{l}\text { WYA. L16\& } \\
\text { L17 }\end{array}$ & $\begin{array}{l}\text { To see Your smile } \\
\text { I would pass every trial }\end{array}$ & 4 & $13 \%$ \\
\hline & & & ToL. L20-L22 & $\begin{array}{l}\text { Trials of life upon me } \\
\text { Are more precious than } \\
\text { diamonds and gold } \\
\text { Tested with fire I may be }\end{array}$ & & \\
\hline & & & FW.L7\&L8 & $\begin{array}{l}\text { Need to get something off my } \\
\text { mind } \\
\text { Don't let this silence be } \\
\text { misunderstood }\end{array}$ & & \\
\hline & & & MmS.L4\&L5 & $\begin{array}{l}\text { But this waiting comes with } \\
\text { Trials and challenges }\end{array}$ & & \\
\hline & Peace & $\checkmark$ & WYA. L1\&L2 & $\begin{array}{l}\text { My best times } \\
\text { When I felt close to You }\end{array}$ & 1 & $3 \%$ \\
\hline & $\begin{array}{l}\text { Self-reliance and } \\
\text { Potential }\end{array}$ & $\checkmark$ & WYA. L9 & $\begin{array}{l}\text { Wherever You are, I'll find } \\
\text { You }\end{array}$ & 4 & $13 \%$ \\
\hline & & & WYA. L29 \& L30 & $\begin{array}{l}\text { Wherever You may be } \\
\text { I will search till we meet }\end{array}$ & & \\
\hline & & & ToL. L23 & $\begin{array}{l}\text { But I know I'll come out } \\
\text { stronger in this world }\end{array}$ & & \\
\hline & & & MmS. L23 & Something known only to me & & \\
\hline & $\begin{array}{l}\text { Self Discipline } \\
\& \\
\text { Moderation }\end{array}$ & $\checkmark$ & ToL.L13-L15 & $\begin{array}{l}\text { Cause I don't need anyone } \\
\text { Nor anything in life } \\
\text { But You }\end{array}$ & 3 & $9 \%$ \\
\hline & & & FW.L6 & $\begin{array}{l}\text { But my mind says: "Don't be a } \\
\text { fool" }\end{array}$ & & \\
\hline & & & MmS. L12 & Help me find my way & & \\
\hline & Loyalty \& & $\checkmark$ & WYA. L13 & Wherever You be, I'll be with You & 3 & $9 \%$ \\
\hline & ability & & WAY. L18\&L19 & $\begin{array}{l}\text { Desperately I await } \\
\text { The day when I'm by Your side }\end{array}$ & & \\
\hline & & & WYA. L21\& L23 & $\begin{array}{l}\text { Wherever You may be } \\
\text { I'll follow till I see } \\
\text { In my heart You will be }\end{array}$ & & \\
\hline & Respect & $\checkmark$ & ToL. L27 & If that's what You decree & 1 & $3 \%$ \\
\hline Values & & & & & & \\
\hline of & Love & $\checkmark$ & Sa.L8 \& L9 & & 1 & $3 \%$ \\
\hline Giving & & & & $\begin{array}{l}\text { We're here for a day or two... } \\
\text { Let me show my way... }\end{array}$ & & \\
\hline & $\begin{array}{l}\text { Sensitive \& } \\
\text { Unselfishness }\end{array}$ & $\checkmark$ & $\begin{array}{l}\text { ToL. } \\
\text { L1\&L2 }\end{array}$ & $\begin{array}{l}\text { My life is not the same } \\
\text { When I'm too concerned by } \\
\text { what they say }\end{array}$ & 4 & $13 \%$ \\
\hline & & & ToL.L3 & $\begin{array}{l}\text { Why should I? When I have } \\
\text { You }\end{array}$ & & \\
\hline & & & MmS.L18 & I feel that I've lost touch & & \\
\hline & & & Sa.L11-L13 & I pray for a day & & \\
\hline & Kindness and & $\sqrt{ }$ & Sa.L11-L13 & When there'll be & 2 & $6 \%$ \\
\hline
\end{tabular}


Gestiana, Kuryani, Septiyana, Educational values...

\begin{tabular}{|c|c|c|c|c|c|}
\hline \multirow[t]{2}{*}{ Friendliness } & & & Justice and unity & & \\
\hline & & Sa.L8 & We're here for a day or two... & & \\
\hline \multirow[t]{3}{*}{$\begin{array}{l}\text { Justice and } \\
\text { Mercy }\end{array}$} & \multirow[t]{3}{*}{$\checkmark$} & Sa.L14 & $\begin{array}{l}\text { Where we put aside our } \\
\text { differences }\end{array}$ & \multirow[t]{3}{*}{3} & \multirow[t]{3}{*}{$9 \%$} \\
\hline & & MmS.L29 & $\begin{array}{l}\text { That on that day You'll forgive } \\
\text { me }\end{array}$ & & \\
\hline & & MmS.L32 & I beg for Your mercy & & \\
\hline \multicolumn{4}{|l|}{ SAll Data } & 32 & 100 \\
\hline
\end{tabular}

The results also showed there are thirty two of types educational values contained in song lyrics. With the following percentages:

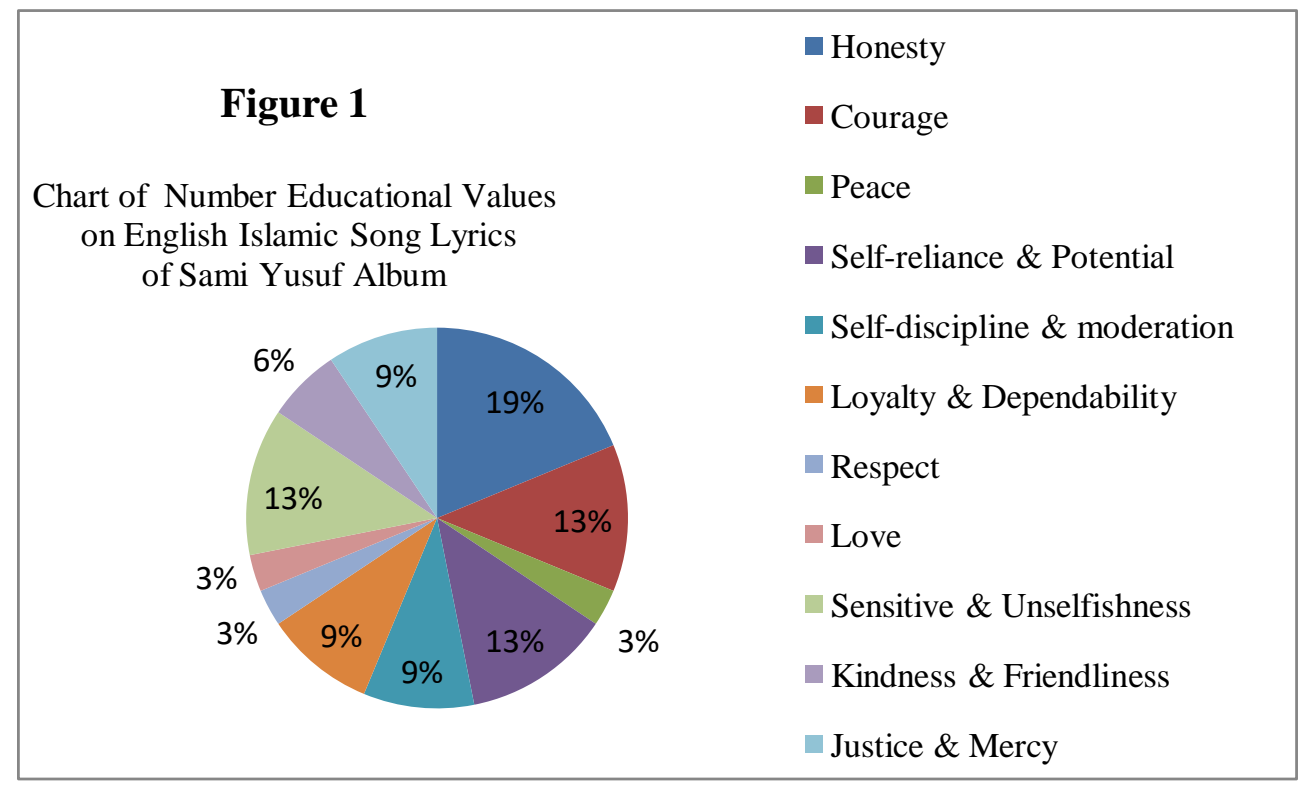

Figure 1. Chart of Number Educational Values on English Islamic Song Lyrics of Sami Yusuf Album.

Based on the chart above, the highest percentage of educational value is honesty which is found about 6 times, which has percentage 19\%. After that, the types of values are courage, self-reliance \& potential, and sensitive \& unselfishness which are found 4 times, which has percentage of $13 \%$. Then, the types of values are self-discipline \& moderation, loyalty \& dependability, and also justice \& mercy which are found about 3 times, which have percentage of $9 \%$. Following that, the values of kindness and friendliness are discovered, each with a percentage of $6 \%$. The last one, the values which are only found once are peace, respect, and love, which has percentage of $3 \%$.

\section{DISCUSSIONS}

The researchers reveal that not all the type of educational values is found in the song lyrics of Sami Yusuf song. Researchers only finds a few types contained in the song lyrics. The educational value is based on Eyre that educational value covers in two kinds. The kinds 
of values are values of being and values of giving. In values of being consists honesty, courage, peace, self-reliance and potential, self discipline and moderation, and fidelity \& chastity. While in values of giving consists loyalty \& dependability, respect, love, unselfishness \& sensitive, kindness and friendliness and last justice and mercy. Whereas the educational values that are found in the song lyrics of Sami Yusuf are honesty, courage, peace, selfreliance \& potential, self-discipline \& moderation, loyalty \& dependability, respect, love, sensitive \& unselfishness, kindness \& friendliness, and justice \& mercy.

After the researcher finds the educational values, researchers explain of its representation. There are eleven types of educational values that are analyzed by researchers. Here, the researchers give an explanation about its representation of each value. One of the explanation of representation is courage. Courage is defined as a person's willingness to risk anything, including a problem, a hazard, a person, and so on.

And here, the researcher gives a percentage about the moral and educational values that are found. The percentage of moral value in the song lyrics as follow:

Table 2 Percentage of Data Finding in Educational Value

\begin{tabular}{|l|l|l|}
\hline No & \multicolumn{1}{|c|}{ Educational Value } & Percent \\
\hline 1. & Honesty & $19 \%$ \\
\hline 2 & Courage & $13 \%$ \\
\hline 3. & Peace & $3 \%$ \\
\hline 4. & Self-reliance \& potential & $13 \%$ \\
\hline 5. & $\begin{array}{l}\text { Self-discipline \& } \\
\text { moderation }\end{array}$ & $9 \%$ \\
\hline 6 & Loyalty \& dependability & $9 \%$ \\
\hline
\end{tabular}

\begin{tabular}{|l|l|l|}
\hline No & \multicolumn{1}{|c|}{ Educational Value } & \multicolumn{1}{|c|}{ Percentage } \\
\hline 7 & Respect & $3 \%$ \\
\hline 8 & Love & $3 \%$ \\
\hline 9 & Sensitive \& Unselfishness & $13 \%$ \\
\hline 10 & Kindness \& friendliness & $6 \%$ \\
\hline 11 & Justice \& mercy & $9 \%$ \\
\hline
\end{tabular}

From that tables, we can see that researchers have found some value in the song's lyrics. The finding data is then processed into percentage to determine the most often and seldom found value.

It is supported by the previous study entitle an analysis of Moral and Educational Values on Madura Folk Songs that In the song " entar Akarang " there are several educational values contained in this track include the value of togetherness and respect and love among their peers for looking shells activity which is done in groups at night(Wakil, 2015, p. 53). In addition, another previous study entitle an analysis of educational values in "Life of Pi" movie showed that educational values in the movie are purity, never give up, not selfish, religious, loyalty, grateful, respect, peace and diligent(Suryati, 2018, p. 56). 
Gestiana, Kuryani, Septiyana, Educational values...

\section{E. CONCLUSIONS AND SUGGESTIONS}

The song lyrics has been analyzed and discussed based on types or indicators of educational values. From the results of data analysis, researcher concluded that 1) The song lyrics have ducational values. The educational value that are found in Sami Yusuf's song lyrics deals with honesty, courage, peace, self-reliance \& potential, self-discipline \& moderation, loyalty \& dependability, respect, love, sensitive \& unselfishness, kindness \& friendliness, and justice \& mercy. 2) The educational value that is more frequently found is honesty which is $19 \%$, while most rarely found are peace, respect, and love that are only found once with a percentage of $3 \%$ each of them.

From the conclusion above, the researchers recommend some suggestions. The following suggestions are 1) for the teacher, the English Islamic song lyrics in Sami Yusuf album can be used as a reference by teachers as a medium in teaching and learning. Teachers do not have to worry because the songs in this album really have a lot of value that can be used as learning, 2) for the next researcher, this research is expected to be a reference and can be helpful for other researchers who will research with the same topic or type of research. The researcher also suggests the other researchers to develop a similar research with different data source and a better research technique.

\section{REFERENCES}

Eyre, L., \& Eyre, R. M. (1993). Teaching your children values. New York: Fireside. http://archive.org/details/teachingyourchil00eyre

Fitria, T. N. (2020). Analysis of Deixis in the Subtitle Movie of "First Kiss." LET: Linguistics, Literature and English Teaching Journal, 10(1), 111-132. https://doi.org/10.18592/let.v10i1.3582

Ghosh, S. (n.d.). Role of V alue Education in Teacher Education. 01(08), 5.

Hudayah, L. F. (2017). An Analysis of Indoensian Moral Values Found in the Song Lyrics Forgive Me Album By Maher Zain. 4th UAD TEFL International Conference, O(0), 330-339.

Luke, J. Y. (2015). The Use of Code-Mixing among Pamonanese in Parata Ndaya Closed-Group Facebook. Lingua Cultura, 9(1), 40-46. https://doi.org/10.21512/lc.v9i1.760

Mafiroh, A., \& Prasetyo, H. E. (2017). Educational Values Analyis Related to KHD's Principle in the Ron Clark Story Movie. JELLT (Journal of English Language and Language Teaching), 1(1), Article 1. https://doi.org/10.36597/jellt.v1i1.924

Meliala, R. R. S., Widodo, S. T., \& Subiyantoro, S. (2017). Educational Values in Children Literary Works by Murti Bunanta. IJOTL-TL: Indonesian Journal of Language Teaching and Linguistics, 2(3), 203-212. https://doi.org/10.30957/ijoltl.v2i3.389 
Miles, M. B., Hubberman, A. M., \& Saldana, J. (2014). Qualitative Data Analysis, A Method Sourcebook. Sage Publication.

Nurpahmi, S. (2015). Improving Listening Skill by Activating Students' Prior Knowledge. ETERNAL (English, Teaching, Learning, and Research Journal), 1(1), 28-38. https://doi.org/10.24252/Eternal.V11.2015.A3

Rahayu, P. S., \& Hizriani, N. (n.d.). English teachers' professional development at Hulu Sungai Selatan. South Kalimantan.

Suryati, S. D. (2018). An Analysis of Educational Values In "Life of Pi" Movie [Undergraduate, UIN Raden Intan Lampung]. http:/ / repository.radenintan.ac.id/4570/

Van Luxemburg, J. (1989). Pengantar ilmu sastra / Jan Van Luxemburg, Mieke Bal, Willem G. Westseijn; diindonesiakan oleh Dick Hartoko. Gramedia.

Wakil, A. (2015). An Analysis of Moral and Educational Values on Madura Folk Songs. Jurnal Ilmiah Bahasa Dan Sastra, 2(1), 47-57.

Wijayanto, M. E. (2020). The Integration of Islamic Values in Implementing of Learning English: Islamic Education Students' Perspective. ETERNAL (English, Teaching, Learning, and Research Journal), 6(1), 18-30. https://doi.org/10.24252/Eternal.V61.2020.A2 